\title{
The DEVELOPMENT AND PROVISION OF EDUCATIONAL SERVICES FOR CHILDREN WITH INTELLECTUAL DISABILITIES IN EGYPT
}

\author{
DESENVOLVIMENTO E PRESTAÇÃO DE SERVIÇOS EDUCACIONAIS PARA CRIANÇAS \\ PORTADORAS DE DEFICIENCIA INTELECTUAL NO EGITO
}

Hala ABDELHAMEED ${ }^{1}$

\begin{abstract}
: this paper aims to providean overview of the development and provision of educational services for children with intellectual disabilities in Egypt. Intellectual disability is a significant sub-average general intellectual functioning existing concurrently with deficits in adaptive behaviour and manifested during the developmental period. Theeducation of children with intellectual disabilities is a right endowed and authorised by the Egyptian government. The Ministry of Education in Egypt is keen to provide those children who have intellectual disabilities, along with other children with special needs, with an appropriate education that addresses their needs and allows them to live in society using their full potential, as typically developing children. Observations and interviews were carried out to collect further information about the educational services the children with intellectual disabilities receive in Egypt. The findings of this study indicated that, despite the efforts exerted by the Ministry of Education, to provide advanced and new services for children with intellectual disabilities, the provision may still need improvements. A series of recommendations was suggested to improve the services that children with intellectual disabilities receive in Egypt.
\end{abstract}

KEYWORDS: Intellectual Disability; Special Education; Inclusion.

RESUM O: esteartigo visa fornecer uma visão geral do desenvol vimento e prestação de serviços educacionais para crianças com deficiência intelectual no Egito. Deficiência intelectual é um prejuízo significante do funcionamento intelectual, concomitantemente a déficits no comportamento adaptativo, e que se manifesta durante o período de desenvolvimento. A educação das crianças com deficiência intelectual é um direito garantido elegitimado pelo governo egípcio. O M inistério da Educação no Egito está empenhado em fornecer a essas crianças, que têm deficiência intelectual, junto com outras crianças com necessidades especiais, uma adequada educação que atenda as suas necessidades e lhes permita viver em sociedade utilizando todo o seu potencial, como crianças com desenvolvimento típico. Observações eentrevistas foram real izadas para coletar informações adicionais sobre os serviços educacionais destinados a crianças com deficiência mental no Egito. Os resultados desteestudo indicaram que, apesar dos esforços promovidos pelo Ministério da Educação, para proporcionar serviços novos eavançados para crianças com deficiência intel ectual, a prestação ainda precisa demelhorias. Uma série derecomendações foi sugerida para mel horar os serviços queas crianças com deficiência intelectual recebem no Egito.

PALAVRAS-CHA VE: deficiência intelectual; educação especial; inclusão.

\footnotetext{
${ }^{1}$ Lecturer of Special Education, Special Education Department, Faculty of Education, Suez Canal University. halabadran@hotmail.com
} 


\section{INTRODUCTION}

Egypt has one of thelargest education systems in theworld, as dassified by the World Bank, with 15.5 million students (over 90 percent enrolled in public schools), 807,000 teachers, and 37,000 schools. Its education system has undergone significant expansion over the last decade, whether expressed in expenditure on education or educational infrastructure (UNESCO, 2006 p.9).

Special education is an important sector of this largeeducation system. The first school for children with special needs was established in 1874 for the education of blind and deaf children. In 1900, another school in A lexandria city was also established, by an English lady, for blind children. The ministry of education, at that time, was becoming aware of the need for specialised teachers for these blind children and opened a new division at a women teacher's college to train teachers for blind children. All efforts were made to educateblind children but therewas no responsetowards children with intel lectual disabilities. The first response was in 1956 when the ministry of Education established the first school for mentally retarded children called "The Institution of M entally Handicapped". Since that time, special education for children with intellectual disabilities has developed and improved with time (MINISTRY OF EDUCATION , 2009).

The dedaration of the Rights of Intellectually Disabled Persons adopted in 1971, secured the rights of the disabled. Its first statement declares: "The mentally retarded person has to the maximum degree of feasibility, the same rights as other human beings, which indudetheright to educational, medical, and economic security, as well as rights corresponding to particular needs in the medical and educational fields and a decentstandard of living. Thesecond declaration states "disabled persons have the rights to respect for their human dignity" (in Declaration of the Rights of Disabled Persons, UN Doc. 1975 in LABA BIDI, 2002; in YVETTE, 2005).

Mentally retarded and mentally handicapped are some of the synonymous terms that are still in use by the government, teachers and professionals, as well as in many societies, to describe children with intellectual disabilities. In UK, the term "general learning difficulties" is chosen instead of other synonyms such as mental handicap, mental impairment, mental subnormality or mental retardation. A differentiation was made between the term "mental handicap" and the term "learning difficulties" by Hulme and Makenzie (1992). They defined mental handicap as a specific pathology which is known to affect mental development. "General learning difficulties" describethe effect of having a mental handicap and this reference is not sufficiently clear for people so they stereotypethemental handicap term. However, there is a big argument regarding the best term that we should use when describing children with intellectual disabilities. It is hard to adopt the "learning difficulties" term in Egypt especially as there is particular confusion in our country between this term and that of specific learning difficulties. Abunian (2001) defined children with learning difficulties as a group of children whose IQ is average but who experience a 
difficulty in one or two specific domains. This difficulty never resulted from any disability such as mental retardation, visual impairment or other environmental causes and in UK is referred to as "specific learning difficulties" (DOCKRELL; MCSHANCE, 1992).

To sum up, the term mental retardation is widely used in Egypt to describechildren with intellectual disabilities who are experiencing some negative effects. This term only focuses on what children cannot do and ignores what they can do. This, in turn, restricts our expectations of these members of society. It may also prevent teachers from providing a widenumber of educational opportunities to let these children learn to their full potential. Furthermore, it may stand against accepting or including these children in the mainstream school in addition to it emphasising the negative effect on the parents' feelings and the children themselves. For thesereasons, wewould prefer to use the term intellectual disability, which is not in common usein Egypt, instead of mental retardation to act in a positive way while we are dealing with these children especially as this term is used occasionally in Egypt. Ministry of Education in Egypt defined intellectual disability as a significant sub-averagegeneral intellectual functioning that leads to limitation of children's abilities to learn and benefit from education in a normal way. This definition totally depends on assessing children's IQ. The American Association of Intellectual and Developmental Disability defined intellectual disability as a significant sub-averagegeneral intel lectual functioning existing concurrently with deficits in adaptive behaviour and manifested during the developmental period from birth until 18years of age (ALSHENAWI, 1997). Children might bedeprived in their general education because of the lack of adaptive behaviour assessment, which, in turn, could increase the number of children who are classified as intellectually disabled.

This study focused on the educational services that the children with intellectual disabilities receive in Egypt. In the sections below the Egyptian education system will be presented along with the views of teachers and parents regarding inclusion.

\section{The distribution Of INTELLECTUAL DisabiLItIES}

Egypt has had a national census every ten years since 1907 containing data about disability. The census provides data about the categories of disabled persons, classified according to ageand sex distribution. The main method, which the census follows is scanning the number of children with disability in homes, schools, hospitals and any other private or public agency. According to the census of 1996, roughly 2,060,536 (3.4\% from the total population) Egyptians are disabled or have special needs (see table 1). This ratio is predicted to increase by UNICEF organization (1993) to be 2,899,180 in the years 2016/2017. Individuals with intellectual disabilities comprise the largest category of this number i.e. 1.5 million (74\% from thetotal number of the special needs). The Central Authority for Public 
Mobilization and Statistics confirmed this data. According to their statistics, there are approximately two million persons with disabilities in Egypt, which represents about 3.5\% of the total population. According to other statistics in 2000, the total number of disabled in Egypt is between $3.85-4.7$ million and 73.3\% of disabled persons in Egypt are mentally disabled (YVETTE, 2005).

A few thousand of them have access to the limited number of adequate services. It is worth noting that this number is not accurate and it may be that the number of children with intellectual disabilities is double that. The rest are dismissed, assumed to be incapable of learning, achieving or leading independent lives. Parents hide such children away and feel ashamed and isolated. They refuse to record their children as handicapped to protect them from having such a label or they may think that reporting their child as disabled is not important or useful.

Table 1 - The number of persons with disability by types in 1996.

\begin{tabular}{lcccc}
\hline Disability type & $\begin{array}{c}\text { Visua } \\
\text { Impairments }\end{array}$ & $\begin{array}{c}\text { Hearing } \\
\text { Impairments }\end{array}$ & $\begin{array}{c}\text { Intellectual } \\
\text { disability }\end{array}$ & $\begin{array}{c}\text { Mobility } \\
\text { Impairments }\end{array}$ \\
\hline No. Disabled Peers & 151,510 & 90,906 & $1,515,100$ & 303,020 \\
Percentage & $7 \%$ & $4 \%$ & $74 \%$ & $15 \%$ \\
\hline
\end{tabular}

Source: UNICEF Country Profile on Disability in Egypt (2002).

\section{THE EGYPTIAN SPECIAL EDUCATION SYSTEM}

TheEgyptian government has developed and improved theeducation of all children with special needs, in particular for children with intellectual disabilities all over the country. Indeed, to date there are many obstacles facing the children in relation to their education but the current efforts are encouraging. Egypt adopted a centralized educational system because all students who eventual ly want to go to college have to take a final test, the grade of which will be the ultimate factor determining if and what colleges the student gets into, so that the education system is the same countrywide. In the following section, an overview of Egypt's special education system all over the country, urban and rural areas will be presented and discussed.

\section{SCHOOLS}

Thereare two types of schools which accept children with intellectual disabilities. Firstly, according to thestatistics from theM inistry of Education (1998) with reference to special education schools, thestatistics are 430 schools for various special needs (visual impairment, hearing impairment, intellectual disabilities) whereas for intellectual disabilities alone, it is 211 schools. This number was 
increased in 2008 to 556 in public schools and 13 private schools as compared with 420 in urban areas and 114 in rural areas for children with intellectual disabilities alone. Tables one and two providea brief summary of the number of schools, classes, students of intellectual disability in Egypt.

Table 2 - The number of intellectual disabilities' schools, classes and students in public and private sectors.

\begin{tabular}{lcccccc}
\hline Education type & & Public & & & Privet & \\
& Schools & Classes & Students & Schools & Classes & Students \\
\hline Nursery & 1 & 4 & 12 & - & - & - \\
Elementary & 430 & 1778 & 4764 & 13 & 76 & 201 \\
Preparatory & 125 & 404 & 1349 & - & - & - \\
Secondary & - & - & - & - & - & - \\
\hline
\end{tabular}

Source: M inistry of Education (2008)

Table 3 - The number of intellectual disabilities' schools, classes and students in urban and rural areas.

\begin{tabular}{lcccccc}
\hline Education type & \multicolumn{3}{c}{ Urban } & & \multicolumn{3}{c}{ Ruler } \\
& Schools & Classes & Students & Schools & Classes & Students \\
\hline Nursery & 1 & 4 & 12 & - & - & - \\
Elementary & 260 & 1438 & 4336 & 93 & 316 & 629 \\
Preparatory & 159 & 369 & 1266 & 21 & 50 & 134 \\
Secondary & - & - & - & - & - & - \\
\hline
\end{tabular}

Source: M inistry of Education (2008)

These special schools are under the supervision of the department of mental education at the ministry of Education. The special schools saccept children with intellectual disabilities with an IQ of 50 to 75 . Before a final acceptance, the child should be put under supervision for two weeks to be sure that he/ she is psychologically stable and has no behavioral disorders. Children should be able to control themselves, to go to the toilet alone, to communicate verbally and not haveany other disability in order to be accepted in school. If not, theschool refuses to accept the child. Because of this, children usually enter the school at the age of eight and graduateat theage of eighteen. Thereare two ways to refer a child with 
intellectual disability to a special school. First, after failing many years in the mainstream school thechild is directed to the psychological clinic for measurement of his/ her IQ, which is sent al ong with his file to a special school. Alternatively, the class teacher recognizes the problems through his/ her work during theschool year and recommends moving him/ her to a special school. Second, parents go directly to the special school to start the procedures to admit their child, depending on doctor's advice or their observations of his/ her behavior. Of course there are some exceptions, a very few children could, with their parent's effort, complete secondary school education and havea secondary school certificate. Thesechildren do not have distinguishing physical characteristics, which enable them to move on from year to year. Whileat a preparatory school a girl with intellectual disabilities was in her year two. She was behind her classmates in many subjects but she could writeand read. Her parents refused to transfer her to a special school. They worked hard with her and hired privateteachers for hometuition. By her parents' efforts sheobtained a commercial secondary school certificatelikemany Egyptian students. Sheis not the only example. Therearea few morecases like hers but the number of these cases is very few. Down syndrome is another special case. This condition is easy to identify so that these children transfer to the special schools from thestart.

Some of the children stay at the school on weekdays and return to their parents for the weekends (every Thursday). They live in flats, which arewell equipped to meet their daily needs, including freemeals. A number of supervisors live with them to monitor their behavior and take care of them. Some parents prefer to leavetheir children at the school for the wholeweek in order to copewith their problems at home or because they live far from the school. This service is available in all special schools nationwideand it is free for all of the children with intellectual disabilities (MINISTRY OF EDUCATION, 1999-2000). Secondly, children with intellectual disabilities who performed well in the special schools or have an IQ of 65 or moreand their age ranged between 5.5-6years could enrol into integrated classes in the mainstream school. These classes are separate from mainstream classes but children with intellectual disabilities meet typically developing children on school day breaks or in somesocial activities. Moredetails will be discussed in the inclusion section.

\section{Teacher Training}

A modest effort was made at the end of 1940s and at the beginning of 1950 s to prepare teachers for special education. This effort was directed towards training teachers for blind children. The preparation of teachers for children with intellectual disabilities began in 1969.

Thereare two ways to choosea teacher to work with the children with intellectual disabilities. Firstly, from teachers who are not graduated from a faculty 
of education but from teachers training college. They work as teachers at the mainstream schools, in particular primary and preparatory schools, and wish to move to work at special schools. Secondly, from teachers who graduated from a faculty of education who might or might not have a special education diploma. The first category consists of $75 \%$ of the special schools' teachers (MINISTRY OF EDUCATION, 2001 - 2002).

Recently, the ministry of education realized the importance of providing a professional training for the unqualified teachers who work with children with intellectual disabilities. The ministry created two types of training to improve teachers' ability to teach children with intellectual disabilities. Firstly, long training, by awarding teachers an internal scholarship, the study period of this scholarship is a year and the candidate should go to a specific place in Cairo to study. Selected professionals from faculties of education nationwide and experts from the general special education management train the teachers. Secondly, short training, the special education teachers who work at the special schools receive a short training for a week or a month in Cairo or Alexandria to improve their ability to teach children with intellectual disabilities.

In a further effort to improve teacher's ability to teach children with intellectual disabilities, the government was keen to learn from other communities' experiences in this field. It awarded many Egyptian faculties of education staff scholarships to study abroad, especially in USA and England. The major aim of these scholarships is to benefit from the state-of-the-art skills in the field of special education in order to be able to provide effective teaching to teachers who will teach children with special needs, including children with intellectual disabilities. Also, the ministry of education cooperated with U.S agency for international development (USAID) to evaluate the special education system and provide the most recent methods to educate children with special needs, including children with intellectual disabilities, in thearea of teaching, teachers training, curriculum and technology.

Despite the previous efforts, which are made by the ministry of education to improveteachers' teaching skills, a reasonable number of the teachers still do not believe that children with intellectual disabilities are able to learn. According to the observations' findings that were collected during fieldwork in this study and in previous studies such as A bdelhameed (2006), Abdelhameed and Porter (2006), in the special school, teachers dealing with children with intellectual disabilities havelow expectations. An explanation of such behaviour may underpin the teachers' desire to teach at a special school. Some teachers like to work at special school to take the extra allowance, which the government give to the teachers who work in the special education sector so they are rel uctant to make any effort to teach these children. However, it is a deeply held belief that children with intellectual disabilities are not able to learn, not only do the teachers bel ievethat but also the majority of society, al though they try to show theopposite 
view their behaviour with these children belies their belief. According to Jones et al. (2002):

\begin{abstract}
Under specific conditions people with mental retardation are able to learn new materials as well as their peers without mental retardation, which could have important implications for education, training, and rehabilitation. In particular, theexperience of success on learning tasks could have positive effects on self-esteem, confidence, and future learning capacity (p. 103).
\end{abstract}

Lack of interest towards teaching children with intel lectual disabilities may be another factor that decreases the teachers' training benefit. The majority of the intellectual disabilities teachers came from the mainstream school. They did not prepare academically or even psychologically to work with this group of special needs children. They felt that this was not the right place to work in so they felt unenthusiastic about working with the children and preferred to withdraw from the class or do other work instead of teaching. In Egypt, teachers have to make a plan for the lesson; this plan should be documented. A regular supervision is done every month or two months to monitor the teachers' performance inside the classroom. This documented plan is very important. In order for them to havea good report all teachers should writeit down accurately. Sometimes thesupervisor does attend the class to see the teacher during the explanation and teaching of the lesson, but in other instances the supervisor depends on this plan to write the evaluation report. In this case theteacher tries to do his/ her best with the children to havea good evaluation. After observing about 22 maths lessons with the children with intellectual disabilities in their special school in Ismailia city, the best lesson was the one that the supervisor attended. The teacher worked hard, asked the children and used the computer in teaching. Teachers should show such performance in all lessons, in all subjects. Indeed not all of the teachers show lack of teaching but they still need to expend more effort in providing better chances for their students.

Lack of knowledge and training on behalf of the teachers may be another explanation, which lies beneath the poor performancein teaching children with intellectual disabilities. They do not have sufficient information about disability and how to teach these children. Although the training may address this point, still more effort should bemade. To date, thetraining is directed towards giving more information than training. The above analysis does not decrease the importance of thetraining, we cannot ignorethefact that professional development of special education teachers has been given priority over the past ten years, but in our view getting involved in the problems and deficiencies may give us an idea about how to improve the special education system. 


\section{Curriculum}

As mentioned before, the Egyptian education system is centralized which means that the special education curriculum is the same in all special and mainstream schools. Children with intellectual disabilities pass through the following stages: Two years for preparation stage, six years for primary education, as the child becomes a young adult (14 years) they are introduced to vocational training for three years. Vocational training provides training in carpentry, plumbing, painting for boys, sewing and other domestic activities for girls (MINISTRY OF EDUCATION, 1998). In the past, thecurricul um for children with intellectual disabilities has not met their educational needs. Their curriculum was similar to typically developing children's curriculum in the mainstream schools. The only difference was in the content of the books. The ministry excluded some chapters from the books assuming that it was too difficult for a child with intellectual disability to learn. There was too much text, few pictures and no interesting content.

Over the last few years, new curricula have been prepared for children with intellectual disabilities from the preparation stageto thethird vocational stage. The appearance and content of their books have been changed completely, they arenow coloured and many pictures havebeen included to present theinformation. According to a former analysis of the maths books for children with intellectual disabilities, these books still need improvement (ABDELHAMEED, 2006). A lot of information was included and the children did not master the basic knowledge to go ahead with learning some advanced skills and information. Furthermore, new vocational training courses were provided such as serving in hotels, gardening, and porcelain decoration and recently some of the children with intellectual disabilities have received training in gardening at the public gardens in Cairo.

\section{The CURRENT Situation IN SPECIAL EDUCATION}

Beforegoing on to describethe Egyptian government's effort in special education reform, an overview of the obstacles and problems that face this sector of the education system will be discussed. As mentioned before, there is a lack of information and statistics on the number of children with intellectual disabilities in Egypt. There is a qual itative and quantitative shortage in the special education professionals who can deal with and teach children with intellectual disabilities especially because most of the teachers who work in the special schools are unqualified. The number of faculties of education that train qualified special education teachers is small. Furthermore, the services do not reach all children with intellectual disabilities nationwide, in particular, children who live in the countryside and remote areas.

Theprofile of thechild with intellectual disability in the mass media is not adequate. Television programs describethis group of children as if they deserve 
pity and mercy "This poor child cannot do anything so we have to help him/her". This gives a negative view regarding the child's ability to live independently in society. The mass media advertisements focus on the faces of children with Down syndrome to convey this message. Anyone can recognize with ease that children with Down syndrome are different from other children, as they have different facial and physical features. The public may not believe that any other child with normal physical characteristics has intellectual disability. M others advocate their children's ability by emphasising that their children are good, have no problems and are similar to their sisters and brothers. They do not understand why they cannot learn. That is why the mass media focus on the children with Down syndrome in their programs to convince the society that the children with intellectual disabilities need some help.

One of the strengths of the Egyptian law is to give the opportunity for the special needs education to work. Five percent of jobs are reserved for individuals with special needs, including children with intellectual disabilities, at a wide range of agencies, schools, universities etc. Social Rehabilitation Law No.39 stated: Every disabled citizen has the right to benefit from rehabilitation services. Any trained person with a disability should be given a license to enrol at manpower offices to enjoy the right provided for him under the provision of medical fitness in case of public services because of his defect, as indicated in the rehabilitation certificate. In 1975, the quota of disabled was increased from two to five percent of workers in any business with over 60 employees whether in the public or private sector (YVETTE, 2005).

The government took the following steps to develop this sector of the education system and to surmount the previous problems. First, developing five schools for intellectual disabilities in the Cairo governorate. Second, the central integrated welfare society included five other schools for development of premises, content and furniture. Third, the pupils of intellectual disabilities have been integrated into fifty regular schools in the different governorates nationwide, beginning with theschool year 2001/2002. Fourth, thirty classes for students with special needs, including children with intellectual disabilities, were annexed to private schools (SHEHAB et al., 2004).

The improvement covered most of the elements of the educational system for children with special needs including children with intellectual disabilities represented by the following: establishing introduction of rooms which did not exist in the schools, to provide new services such as a family reception room, computer lab, communication room, gymnasium etc. The number of the schools and classes of those with intellectual disabilities al ong with other children with special needs have increased. The government has encouraged parents, to send their children with special needs, especially intellectual disabilities children, who are deprived of possible educational opportunities, to such schools. Recently, it is noticeable that the number of pupils who enrolled in the special schools has increased and the number of teachers has also increased (SEHAB et al., 2004). 
With regard to the development that has taken placein thecurriculum, new curricula have been prepared for pupils with intellectual disabilities from the preparation stage to the third vocational grade. As mentioned before, there were some special schools developed through the ministry development plan of the special education system. These schools have been equipped with the computer laboratories to serve the curriculum. The ministry provided the special needs workers with a number of direct and indirect training programs to enhance the skills of everyone who works in thespecial schools, including SLD schools. Finally, a hot line was established to provide a direct consultation for the children and their families to overcome obstacles that they might face (SEHA B et al., 2004).

\section{INCLUSION}

Inclusive education has evolved as a movement to challenge exclusionary policies and practices and has gained momentum over the past decade. Inclusion has becomethemost effective approach to address the learning needs of all students in regular schools and classrooms (HOLDEN; STEWART, 2002).

Theterm 'inclusive education' is nowadays broadly conceptualized to includestudents from different backgrounds and with different languages, as well as students with disabilities (ASH MAN , 2002). However, for the purposes of this study, the definition of inclusion (Fuchs and Fuchs, 1994) of will be used. They defined the inclusion term as partial or full inclusion in regular classrooms, with thelevel of inclusion being dependent upon the severity and number of disabilities and the level of additional support available for that student.

Narrowing the gap between typically developing children and those with special needs is the major aim that lies beneath special education reform in Egypt. The government is keen to provide equal and appropriate educational opportunities for thesechildren in an "Education for All" program. Thegovernment adopted partial inclusion as a first step towards full inclusion for children with intellectual disabilities in the mainstream schools. Egypt is one of the countries that adopted a dual public and religious education system. For a long time, religious education has preceded the governmental schools in including blind children in the Azhariteschools. Thenature of study in AI - Azhar education system specializes in scientific and religious aspects.

Children with visual impairment (partial or complete), poliomyelitis and physical disability are in a better situation than children with intellectual disabilities. They arefully included in the mainstream schools (public, privateand religious schools) and move automatically according to their level form year to year. They graduatefrom a widevariety of faculties and some of them are working as doctors in the public hospitals. Gaad (2001) pointed to this as:

In reality, thechances of a blind child being included in a regular neighbourhood school are far greater than even considering including a child with Down syndrome from the same neighbourhood in the same school. (p. 201) 
However, recently, children with intellectual disabilities have been integrated into fifty mainstream schools nationwide. Thenumber of classes annexed to general education amounted to 244 classes nationwide. Thechildren arestudying in separate classes from typically developing children, in the school. It is worthy of mention here that private schools have preceded the governmental schools in including children with intellectual disabilities to learn with typically developing children in the same class.

However, in our view this is an important step towards spreading the idea of including children with intellectual disabilities in society. Society has accepted the principle of educating blind children in religious education but is unable to accept including children with intellectual disabilities in the mainstream schools, finding it an abhorrent idea. So integrating children with intellectual disabilities in the mainstream school may improvethe society's attitudes regarding inclusion.

Parents and special education teachers who were interviewed in this study showed negative attitudes towards educating children with intellectual disabilities in the mainstream schools. Mothers were very reluctant to enrol their children in the inclusive schools; they preferred to travel from their own city to another to enrol their children in the special school. They said that their children receive more services and care in special schools than in regular schools. Two mothers had withdrawn their children from theregular school becausethetypically developing children teased them. Special education teachers also have negative attitudes towards educating children with intellectual disabilities with their typically developing peers. They wondered how the special education teacher and the regular education teacher would beable to teach thesechildren especially as they have lower IQ scores than their peers. Also, how regular school teachers would teach a child with intellectual disability, especially as the curriculum is difficult and compact and the number of students is large. They ask how these children will learn and meet the requirements of moving from year to year. The deputy of the special school in this study took an opposite view, she said that a child who has an IQ more than 65 would benefit from inclusion, and her opinion is partially positive.

\section{Recommendations}

The recommendations of this study will focus on the most important issues that were reported earlier in this study, in particular including children with intellectual disabilities in mainstream schools. First, regarding the terminology, al though the mental retardation term is still in use in many societies it would be better if government tried to raise the awareness regarding the limitations of using this term. According to Schroeder et al. (2002): 
The term "mental retardation" is currently under attack by many selfadvocates, and caregivers, service providers, educators, and other professionals. It is believed to promotestigma and a negativeimage of persons so labeled. The definition of mental retardation has changed nine times over the past 100 years in the U.S. It will soon change again, to meet the many needs, to reflect gains in knowledge and to promote the dignity and well being of persons affiliated with the term. (p.5)

Second, there is a growing interest by the government in developing the special schools and increasing their number. This policy may hinder the effort which government make for inclusion so there is a great need to restrict the expansion of special education schools to increase the number of inclusiveschools. Especially that building new special schools will cost more money for buildings, new teachers and equipment but this cost could bediminished if the children with intellectual disabilities enrolled into their neighbourhood mainstream schools.

Third, there is a great need to increase the number of faculties of education that prepare both special education and general education teachers, to beableto teach children with intellectual disabilities. Up to now, therearelimited numbers of faculties of education that train special education teachers or general education teachers who are able to identify and teach a child with intellectual disability. Also, the teachers who work already in the intellectual disabilities schools need continuous training and supervision to meet children with intellectual disabilities' educational needs.

Fourth, the curricula should build on the characteristics of children with intellectual disabilities try to meet the requirements of inclusion. Fifth, regarding inclusion, despite the effort that the government established towards including children with intellectual disabilities in the mainstream schools, this effort still needs more improvements. A successful system of inclusion requires that the community believe in the competence of the education system to meet the needs of all students. An obstacle which could face successful inclusion is teachers. Special and general education teachers are unprepared or they don't haveenough knowledge and training about students with intellectual disabilities in order to teach them effectively. Many studies such as McLeskey and Waldron (2002), Shade and Stewart (2001), and Gaad and Khan (2007) reported that general and special education teachers stated that they needed extra training in the area of teaching students with special needs in order to be adequately prepared. A concern raised by special education teachers in this study is how the general education teachers will meet the needs of children with intellectual disabilities, so collaboration is an important factor lag behind succesfful inclusion. This is especially valuable between special education and general education teachers. Leyser and Tappendorf (2001) found it was useful if special education and general education teachers trained together in in-services or pre-services so they could share ideas and learn skills on how to collaborate effectively, team, and teach together. It is important for 
the special education and general education teachers to collaborate on issues, concerns, and appropriate instruction and structure in the classroom for students with disabilities (VOLTZ et al., 2001).

Furthermore, teachers, parents, students and the whole society should have positive attitudes toward inclusion in order for it to be successful. In addition to positive attitudes, the whole school needs to be supportive of inclusion. Supportive administration is also important because they have to give the rest of thestaff the support and resources they need in order to feel good about the changes toward inclusion (KOCHAR et al., 2000). Furthermore, parents and teachers attitudes towards inclusion area very crucial factor which could lead to successful inclusion. Parents attitudes in this study towards inclusion was negative, they supported special schools and worked against indusiveschools. So thegovernment should find a way to improve the attitudes of parents of children with intellectual disabilities towards inclusion by training programmes or other means.

Finally, theroleof the mass media should shift towards demonstrating the strengths of children with intellectual disabilities and focusing on what they can do. Although somepreparation and rehabilitation centres focus on thestrengths of their children it is still superficial. Educators and advocates of the rights of children with intellectual disabilities should raisetheir voices through mass media to convey their views regarding the ability of children with intellectual disabilities to learn and how they can develop their abilities in the same way as typically developing children. Again, government, parents, teachers, professionals, educators, mass media and the whole society should work together to support these children who have the right to live with their full potential in the society.

\section{References}

ABDELHAMEED, H. R.; PORTER, J.Counting in Egyptian children with Down Syndrome. International Journal of Special Education, v.21, n.3, p. 176- 187, 2006.

A BDELHAMEED, H. R. Counting and Egyptian children with D own Syndrome. Unpublished PhD Thesis, University of Birmingham, Birmingham, England, 2006.

ABUNIAN, I. Learning D isabilities: teaching methods and cognitive strategies. Special Education A cademy, Alriydh, 2001.

ALSHENAWI, M. M. M ental Retardation: causes, diagnosis and programmes. Dar-Garieb Publisher: Cairo, 1997.

ASHMAN, A. F. Society, culture and education. In: ASHMAN, A. F.; ELKINS, J. (Eds.). Educating children with diverseabilities. Frenchs Forest, NSW: Pearson education, 2002. p.5-40.

DOCKRELL, J.; MCSHANCE, J. Children's learning difficulties: A cognitiveA pproach. Oxford: Blackwell, 1992.

FUCHS, D.; FUCHS, L. S. Indusive schools movement and the radicalization of special education reform. Exceptional Children, v.60, p.294-309, 1994. 
GAAD, E.; KHAN , L. Primary mainstream teachers' attitudes towardsinclusion of students with special educational needs in the private sector: a perspectivefrom Dubai. International journal of special education, v.22, n. 2, p. 95-109, 2007.

GAAD, E. E. Educating children with Down's syndrome in the United Arab Emirates. British Journal of Special Education, v. 28, n. 4, p.195-203, 2001.

HOLDEN , B.; STEWA RT, P.Theinclusion of students with Down syndromein N ew Zealand schools. D own syndrome N ews and U pdate, v.2, n.1, p.24-28, 2002.

HU LM E, C.; M A CKEN ZIE, S. Working memory and severe learning difficulties, Lawrence Erlbaum, H ove, U K, 1992.

JONES, R., VAUGHAN, F.; ROBERTS, M. Mental retardation and memory for spatial locations. A merican A ssociation on M ental Retardation, v.107, n. 2, p.99-104, 2002.

KOCHAR, C.A.; WEST, L.L.; TAYMENS, J. M. Successful inclusion: Practical Stratigies for a shared responsibility. U pper Saddle River, NJ: Prentice H all, Inc, 2000.

LABABIDI, L.; EI ARABI, N. Silence No More. AUC , Cairo. In: MALEK, Y. A. Inception Report on Intellectually Disabled in Egypt: RightTo LiveAssociation for the Intellectually Disabled, NGO, 2005. http:/ / www.gtid.net/ countryreport/ Ms_Abdel_Malek_Yvette.pdf

LEYSER, Y.;TAPPENDORF, K. A reattitudesand practices regarding mainstreaming changing? A case of teachers in two rural school districts. Education , v.121, n.4, p.751-761, 2001.

MCLESKEY, J.; WALDRON, N. L. School change and inclusive schools: Lessons learned from practice. Phi Delta Kappan, v. 84, n.1, p.65-73, 2002.

MINISTRY OF EDUCATION (n. d.). The history of the disability in Egypt. Tuesday $20^{\text {th }} 2007$ from: http:/ / www.emoe.org/ Arabic/ Teacher/ private/ history/

MINISTRY OF EDUCATION, Statistics from TheM inistry of Education .Cairo, Egypt, 1999-2000.

MINISTRY OF EDUCATION, Statistics from TheM inistry of Education. Cairo, Egypt, 2001-2002.

MINISTRY OF EDUCATION, Statistics from The M inistry of Education. Cairo, Egypt, 2008.

MINISTRY OF EDUCATION, Statistics from The M inistry of Education. Cairo, Egypt, 2009.

Ministry of Education. Statistics From TheM inistry of Education. Cairo, Egypt, 1998.

SCHROEDER, S. R.; GERRY, M.; GERTZ, G.; VELAZQUEZ, F. Usage of theTerm “M ental Retardation:" Language, Imageand PublicEducation. 2002. Final project report from: http:/ / www.ssa.gov/ disability/ MentalRetardationReport.pdf

SHADE, R. A.; STEWART, R. General education and special education pre-serviceteachers' attitudetoward inclusion. Preventing School Failure, v.46, n.1, p. 37-41, 2001.

SHEHAB, M., et al. Development of Education in A rab Republic of Egypt 2000- 2004. $N$ ational Center for Educational Research and D evel opment. Cairo, Egypt, 2004

UNESCO. D ecentralization of E ducation in Egypt. Country Report at the UNESCO Seminar on "EFA Implementation: Teacher and Resource Management in the Context of Decentral ization" H yderabad, India, 2006.

UNICEF. The study of disability in Egypt. 1993. From: http:/ / www.ndp.org.eg/ ar/ conferances/2nd_conf/ papers/ edu_2.aspx 
ABDELHAMEED, $H$.

UNICEF. Country Profile on Disability in Egypt. 2002. From: http:/ / siteresources.worldbank.org/ DISABILITY/ Resources/ Regions/ MENA/ JICA_Egypt.pdf

VOLTZ, D. L.; BRAZIL, N.; FORD, A. What matters most in inclusiveeducation: A practical guidefor moving forward. Intervention in School and Clinic, v.37, n.1,p. 23-30, 2001.

YVETTE, A. M. Inception Report on Intellectually Disabled in Egypt: Right To Live A ssociation for the Intellectually Disabled, NGO, 2005. http:/ / www.gtid.net/ countryreport/ Ms_Abdel_Malek_Yvette.pdf

Received: 22/ 12/2009

Reformulated: 24/ 02/ 2010

Approved: 05/ 03/ 2010 